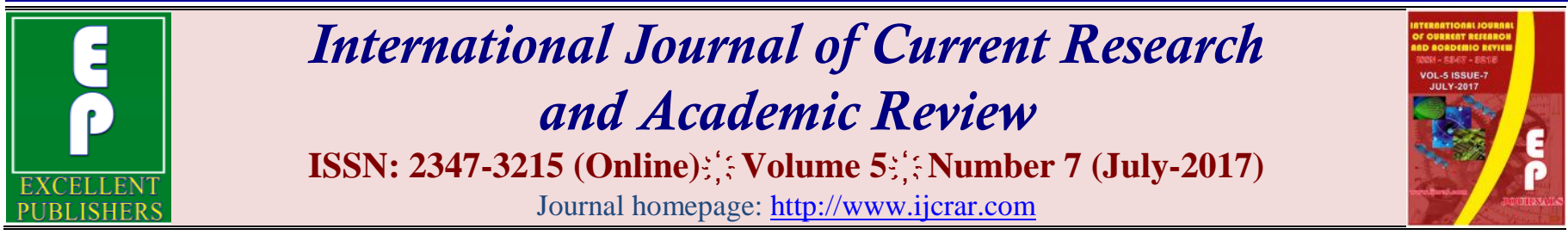

doi: https://doi.org/10.20546/ijcrar.2017.507.007

\title{
Survey of the Anthropic Actions and the Urban Woody Flora Exploitation in Brazzaville (Congo)
}

\author{
Victor Kimpouni*, Marie-Yvette Lenga-Sacadura, Roche Collin Nkounkou-Loufoukou and \\ Josérald Chaîph Mamboueni
}

École normale supérieure, Université Marien Ngouabi, BP 237, Brazzaville, Congo

*Corresponding author

\section{Abstract}

The background of this survey is the management of the urban arboreal diversity in Brazzaville and its link to the endogenous knowledge of the populations. It focuses on the traditional pharmacopeia and the ecological advantages of the urban forestry. The ethnobotanic inventory, based on the anthropogenic sampling of the organs revealed 7 species of which $86 \%$ arealloctonous. The phytogeographic data showed that $57 \%$ among them come from Asia, and only $43 \%$ from central Africa dense forests. On the traditional pharmacopeia aspect, it appears that the taxa intervene in about thirty illnesses and symptoms. According to Africa WHO classification, 11 fields of illnesses and symptoms out of 17 are covered by this survey. Infectious and parasitic illnesses are those that have a very high rate of prevalence. A look on the origins of the aforesaid taxa shows that, there is an appropriation or even an acquisition of new knowledge about phytotherapies. Despite the beneficial effect of these plants, they are always managed like trees of avenue and public gardens. There is no protective and/or back-up measure taken in spite of the senescence that affects them and the uncontrolled harvest of their organs such as roots and barks. The traditherapists needs satisfaction create wide empty areas, and the most important of which are noticed on Peltophorum pterocarpum with $3.15 \pm 0.14 \mathrm{~m}^{2} /$ tree whereas the average $\mathrm{dbh}$ is of $0.55 \pm 0.03 \mathrm{~m}$. This way of taking organs sample weakens the individuals while disrupting their metabolic functions and leading some malformations simultaneously as the brooms of witches; without forgetting the exhibition of the internal tissues to the cryptogamic germs and to the borers insects.
\end{abstract}

\section{Article Info}

Accepted: 02 July 2017

Available Online: 20 July 2017

\begin{tabular}{l} 
Keywords \\
\hline Congo, \\
Floristic diversity, \\
Urban forestry, \\
Barking, \\
Traditional pharmacopeia, \\
Illnesses and symptoms.
\end{tabular}

\section{Introduction}

The interest of the vegetation cover of the Brazzaville city was the subject of a management by the city administrators since the 1938 with the setting aside of 240 hectares of natural forest named "Patted'Oie" composed by Eucalyptus sp., Pinus sp. and a mixture of local species. The objective of this approach was to preserve the forest biodiversity and scientific interest.
However, we are witnessing a decrease in this area due to intensive urbanization and a lack of real integration into an efficient urban forestry management system.

In parallel with this phenomenon, Brazzaville floriculture has been enriched with the exotic trees "planting" especially along the main roads, green spaces and in 
homes concessions (Mbouba, 2007). Besides taxa (Jacaranda mimosoides, Hymanaea courbaril, Aleurites moluccana) which have disappeared for no real reason, all are senescent with critical populations. Some species are in more weakened by their exploitation as phytotherapeutic drugs, but also by their no-renewal and/or no-replacement. These practices limit greatly the development of the urban forestry in Brazzaville.

Several studies exist on Brazzaville floriculture (Koussibila-Dibansa and Makaya, 1977; Mounié, 1999; Nkondi and Mabiala-Tsimba, 1999; Kiangana-Ngoyi and Kalath, 2000;Nzala and Miakodila, 2000; Mbouba, 2007; Niamba, 2007; Ndembe, 2008; Gakosso, 2009; Mbou, 2009; Kimpouni et al., 2013a,b, 2014; NkounkouLoufoukou, 2013), but none of them was treated either the causes, consequences of the phenomenon of stripping the tree barks of Brazzaville city.

Despite a collective awareness of ecological and aesthetic benefits of trees, specimens of streets and public spaces have a stripping level of the barks that offers a bleak picture; contrasting with idea of the sustainable management of biodiversity. It is by crossexamining on the phenomenon of stripping the barks of trees, which affects almost all trees of avenues and parks that this reflection has emerged.

Which are the fundamental reasons that lead to completely disfigure the trees barks, disrupt their metabolism and sometimes lead to their death? These questions lead us to (i) question managers of the city to identify authors and to know their assessments of the scale of the phenomenon; (ii) to conduct an ethnobotanical survey of traditional healers who are incriminated.

The aim of this study is to expose the correlation which exists between the needs of traditional society, through local knowledge and the sustainable management of plant biodiversity, including urban arboriculture in Brazzaville.

\section{Material and method}

\section{Presentation of the setting}

Brazzaville, our study locality, is the political capital of $\left(4^{\circ} 10\right.$ 'and $4^{\circ} 20^{\prime} \mathrm{S}, 15^{\circ} 10$ 'and $15^{\circ} 20^{\prime} \mathrm{E}$ ) the Republic of Congo $\left(11^{\circ} 11\right.$ 'E, $5^{\circ} 00^{\prime} \mathrm{S}, 18^{\circ} 35$ 'E, $3^{\circ} 34$ 'N) (Fig. 1). The climate of low-Congolese types (Fig. 2), is characterized by average annual temperatures of about $25^{\circ} \mathrm{C}$ with low thermal oscillation amplitude from 4 to $6^{\circ} \mathrm{C}$ (Aubréville, 1949; Vennetier, 1977; SambaKimbata, 1978; Samba et al., 2008; Samba and Nganga, 2011). The annual average sunstroke is between 1100 and 1800 hours (Samba et al., 2008; Samba and Nganga, 2011). The average rainfall is about $1200 \mathrm{~mm} /$ year. The relative humidity is greater than $70 \%$. It presents an absolute minimum in August and September and a relative minimum in February and March. As for the evaporation, the relative minimum is observed in June and the absolute maximum from August to September (Vennetier, 1977; Samba-Kimbata, 1978). This climate is characterized by the alternation of two seasons of unequal length. The rainy season, hot and humid extends from October to May with a slowdown in rainfall in the months of January and February (Vennetier 1977; Samba et al., 2008; Samba and Nganga, 2011). The dry season runs from June to September.

Geologically, two main stratigraphic series are distinguished in Brazzaville (Cosson, 1955): the Batéké trays composed of silicified sandstone sands; and the Stanley Pool overling the Inkisisandstone. Soils are lateritic, highly desaturated, poor exchangeable and highly permeable ground because of the sandy substrate allows the migration of the soil solution (Denis, 1970).

The vegetation is a marker of urban arboriculture, reflecting the conversion of natural forest into artificial one. Its foundations are none nothing but then the natural and artificial mesophilic forests of "Patted'Oie" typically composed of Pinus sp. or Eucalyptus sp. Apart from that forest, there are also avenues 'trees, parks, gardens, and squares. The woody flora is essentially immigrant (Mbouba, 2007). Finally, vacant lands, usually from forest conversion, have a graminaceous floristic composition.

\section{Study material}

The study material was identified in the urban area of Brazzaville. These are essentially trees which have the barks stripping due to the anthropogenic action. The removal of external bodies induces exposure of internal organs to natural weathering, pathogenic microorganisms, the borers, etc. Considering these data, observations focus on the health status of individuals (presence of fungi, borers insect, physiological defects, rot, partial drying and / or total, etc.), the frequency of sampling and renewal organs, and the extent of peeled 
surfaces unhealed. Material was ordered according to the APG III (Angiosperm Phylogeny Group, 2009) and taxonomic nomenclature followed is that of Lebrun and Stork (1991-1997). For each species, the parts used, the phytogeographical distribution and status (immigrant or native, spontaneous or cultivated) were mentioned.

\section{Research methodology}

The research method was based on three complementary areas that are (i) the bibliographic compilation, (ii) the botanical inventory, and (iii) the ethnobotanical survey.

\section{Bibliographic compilation}

The bibliographic compilation allowed to inventory data on urban forestry in Brazzaville. This compilation understands floristic data (Mounié, 1999; KianganaNgoyi and Kalath, 2000; Mbouba, 2007; Niamba, 2007; Ndembe, 2008), ethnobotanical (Bouquet, 1969; Adjanohoun et al., 1988; Koussibila-Dibansa and Makaya, 1997) and the sustainable management of Brazzaville flora (Nzala and Miankodila, 2000; Kimpouni et al., 2013a, b, 2014; Nkounkou-Loufoukou, 2013).

\section{Botanical inventory}

In accordance with the administrative organization of the Brazzaville city and to optimize the inventory oftrees whose barks have been stripping, urban space was divided into 9 zones: Makélékélé, Bacongo, Poto-Poto, Moungali, Ouenzé, Talangaï, Mfilou, Djiri, and Madibou (Fig. 1). Data collected relate to (i) the systematic enumeration of all individuals species whose barks have been stripping (standing dead and alive), (ii) the extent of the surface peeled by individual and (iii) the diameter at breast height (dbh) of the individual.

\section{Ethnobotanical survey}

The ethnobotanical survey involves only old people who have knowledge about plants virtues and the way of transmission of indigenous knowledge (inheritance, initiation or training) on species recorded. It is based on direct interviews with open questions (Martin, 1995), which the interest of is to elucidate the reasons for stripping the barks of the trees. The interviews, based on both the plant and its uses, traditional healers and people interested (in their respective plot). In connection with the 7 species recorded, thirty healers were approached and only 7 recognized to use at least one of the plants. Thus, they are the basis of informants. For each of the identified plants, we have listed treated diseases and symptoms and / or relieved. Traditional healers are coded according to their residence and the number, as follows: Makélékélé (MKL1, MKL2); Madibou (MDB); Moungali (MGL) Bakongo (BCG); Mfilou (MFL1, MFL2).

\section{Results and Discussions}

\section{Floristic data}

The inventory counts 7 species distributed into six genera and 4 families (Table 1). All species together, 4534 trees are counted of which $20.67 \%$ marked by the tangible signs of anthropogenic stripping barks (Fig. 3). In terms of usage in quality cultivars in Mangifera indica, the proportion of barking individuals was higher. Indeed, improved local varieties and / or grafted not amenable to therapeutic practice; only the formerly introduced variety is recommended. It is considered as indigenous by traditional practitioners. This inventory shows that all species involved are under human control, such as trees of avenues, squares and green spaces Gardens.

Except Markhamia tomentosa that may be native of Brazzaville mesophilic forest, all others $(85.17 \%)$ are exotic with a large phytogeographical distribution. 57.14\% come from tropical Asia (Mangifera indica, Terminalia catappa, Senna siamea and Peltophorum pterocarpum). As for Millettia laurentii and Terminalia superba, the origin would be the Congolese rain forests.

In Brazzaville city, all these species are represented by specimens planted along main avenues and in the socalled green public garden. Within the residential concessions one almost notice the permanent presence of varieties or cultivars of Mangifera indica which do not lend themselves to the exploitation of popular virtues.

The bark sampling, be it of the stem or the root, is executed without respect ecological norms. The mechanical action of machetes reaches generally the sapwood and consequently affects (i) the regenerative seated; (ii) the internal and external organs. Thus, consciously or not, the internal organs are exposed to borers insect; to fungal germs, etc. Because of their small diameter, several individuals are almost ringed or are exposed to wide strips. The removal of some trees organs 
induces severe consequences for the metabolism of affected trees.

\section{Evaluation of anthropogenic effects}

The scale of human action is estimated by measuring the surface peeled from the trunk of each individual and the level of achievement of the cambial seat. Observations have shown that Peltophorum pterocarpum and Senna siamea are the most prized species. The respective rates barked trees ranges from 90 to $100 \%$ in the southern areas of the city, while the urban mean is around $55 \%$. In terms of peeled surface Peltophorum pterocarpum leads with $3.15 \mathrm{~m}^{2}$ / tree (Table 2). Senna siamea trees would be most vulnerable to the peeling phenomenon. Often ringed, this species has the largest number of dead individuals on foot. Just inside the campus of the "Ecole Normale Superieure", the rate of the tree mortality exceeds 40\% Senna siamea. Finally, 13 died on the foot of popular cultivar Mangifera indica are identified in the wasteland. Given the high number of inventoried topics and the multitude of existing cultivars in Mangifera indica, the rate of $9 \%$ debarked is actually below the reality because only one of them is suitable for medicinal needs of people. This is the oldest cultivar (the first that was introduced) and is on the verge of senescence in the urban space today. This taxon is usually the main cause of the development of forest groves in savannah areas, symbol of abandoned villages.

\section{Floristic biodiversity and indigenous knowledge}

The survey of traditional healers revealed that only one of them explores all the seven taxa. The individual degree of exploitation of flora varies from 71 to $86 \%$ (Fig.4). The relationship between the degree of exploitation of biodiversity and the level of indigenous knowledge of traditional healers varies from 43 to $86 \%$ in general, except for Senna siamea, Millet tialaurentii and Mangifera indica whose customary unanimity was proved by 7 respondents (Fig. 5).

The convergence of therapeutic uses revealed that $43 \%$ of the taxa are customary in all traditional practitioners (Fig. 5). Concerning the other taxa, there is a reporting discrepancy. The species whose virtues are less exploited is Terminalia superba which meets less than $50 \%$ of traditional healers. However, a small number of traditional healers exploiting a given species does not mean a low peeling of trees barks. Despite the convergence of use which is evident, we have to note that it also expresses a clear divergence between traditional indigenous knowledge in the use of flora (Figs. 4 and 5).

\section{Ethnobotanical data}

In all cases, the removed organs (root bark, stems bark and / or trunk bark) provide a daily herbal source to populations. They are involved in the treatment of about thirty diseases and symptoms associated with more than one sphere of organs (Fig. 6). The ethnobotanical survey showed that each of them is cited about at least four times for different diseases or symptoms (Fig. 7). The classification by sphere of diseases and symptoms indicates the prevalence of infectious and parasitic diseases (Fig. 6). They are followed by infections of the genitourinary organs and symptoms, signs and ill-defined conditions. Indeed, the prohibitive cost of modern medicine arouses a public interest in traditional medicine. Thus, the therapeutic indications about diseases and symptoms correspond to the socio-health data of the area. The diseases and recurrent symptoms which have a prevalence rate of $14.28 \%$ are: stomach ulcer and pain, hernia, hypertension and sterility. Follow the hemorrhoids, coughs and dysmenorrhea with a prevalence of $8.57 \%$. The majority of diseases and symptoms cited represent $77.14 \%$.

The ratio of emerging diseases and the number of taxa involved in their treatments is as follows: malaria with $14.29 \%$ of taxa; hypertension (the arterial high blood pressure) with $42.86 \%$; diabetes with $28.57 \%$; and finally belly and stomachaches with $57.14 \%$. Taxa involved in the treatment of these diseases bring information on the prevalence and importance of organ harvesting.

The Senna siamea involved in the treatment of malaria, high blood pressure, stomach and belly aches; the pterocarpum Peltophorum is quoted in the cases of high blood pressure, stomach and belly aches; Terminalia catappa is related to high blood pressure and diabetes; and finally, the Mangifera indica which is associated with diabetes, belly and stomachaches.

\section{Floristic analysis}

Among the seven taxa which form the basis of this study, Markhamia tomentosa was the only element from Brazzaville flora (Kimpouni et al., 2013, 2014). All others (Millet tialaurentii and Terminalia superba) are from anthropochorie usually conscious, from the Congolese dense forests or other areas of the tropics, 
particularly Asia: Mangifera indica, Terminalia catappa, Peltophorum pterocarpum and Senna siamea. All these exotic species were introduced in Brazzaville for aesthetic purposes; sometimes they seal the connection with the origins (Fleury, 1994; Kimpouni et al., 2013c). Thus they adorn our arteries forming hedges.

Besides this aspect, the place of the tree in the city combines the functions (i) direct such as food, herbal reserve, wood energy, aesthetic, scientific; (ii) indirect, including ecological advantages (physiological function, retention of dust, fight against erosion, climate regulation, shading, carbon sequestration, biodiversity conservation, etc.) as shown by Convery (1990), Duvigneaud (1980), Ozenda (1982). To realize its full potential, the tree must meet a minimum of morphoanatomical criteria reflecting its health. Concerning peeled surfaces and organs of the sampling mechanism, our subjects are in bad shape. Consequently, they cannot successfully fulfill their vital functions to the extent that entropy tends to take precedence over the enthalpy.

Fig.1 Location of inventory areas and natural forests in Brazzaville (Kimpouni et al., 2014)

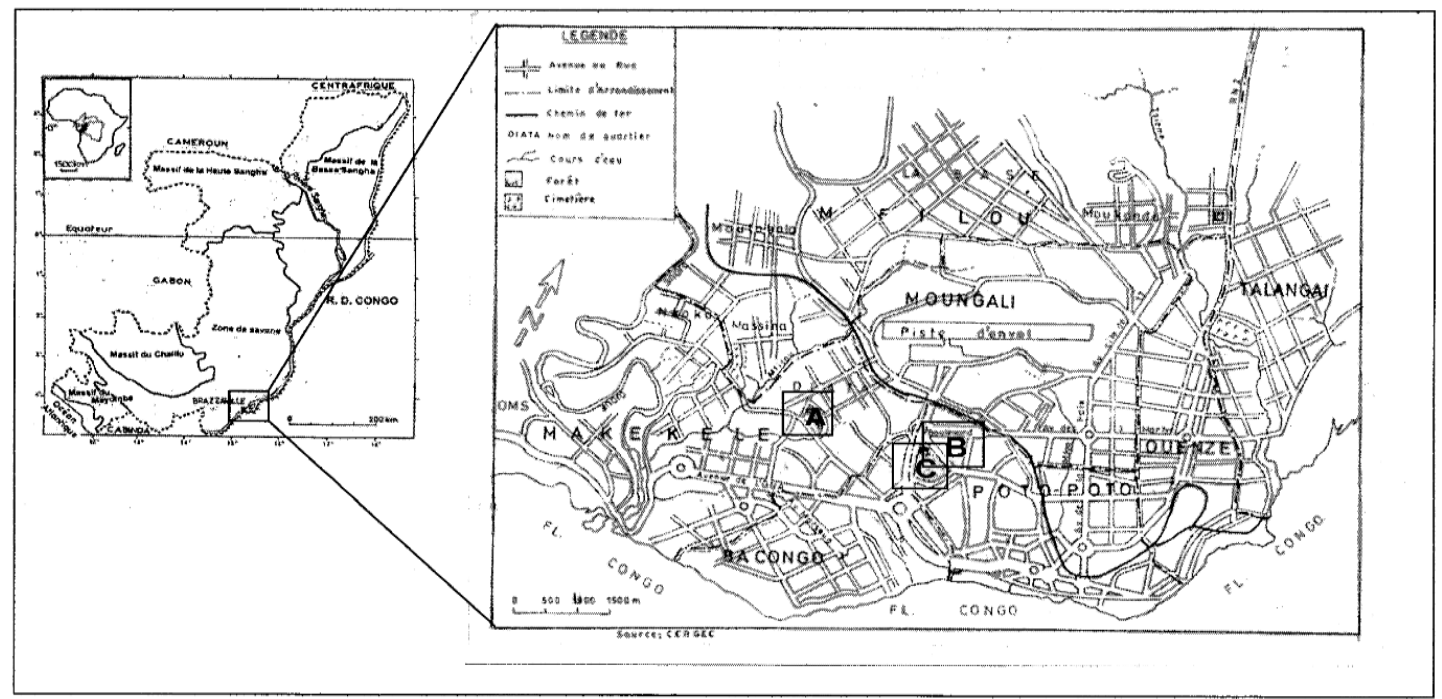

Legend: natural forest of Scientific City forest (A), Parliament House forest (B), Zoologic Park Forest (C).

Fig.2 Ombrothermic curve of the Brazzaville region

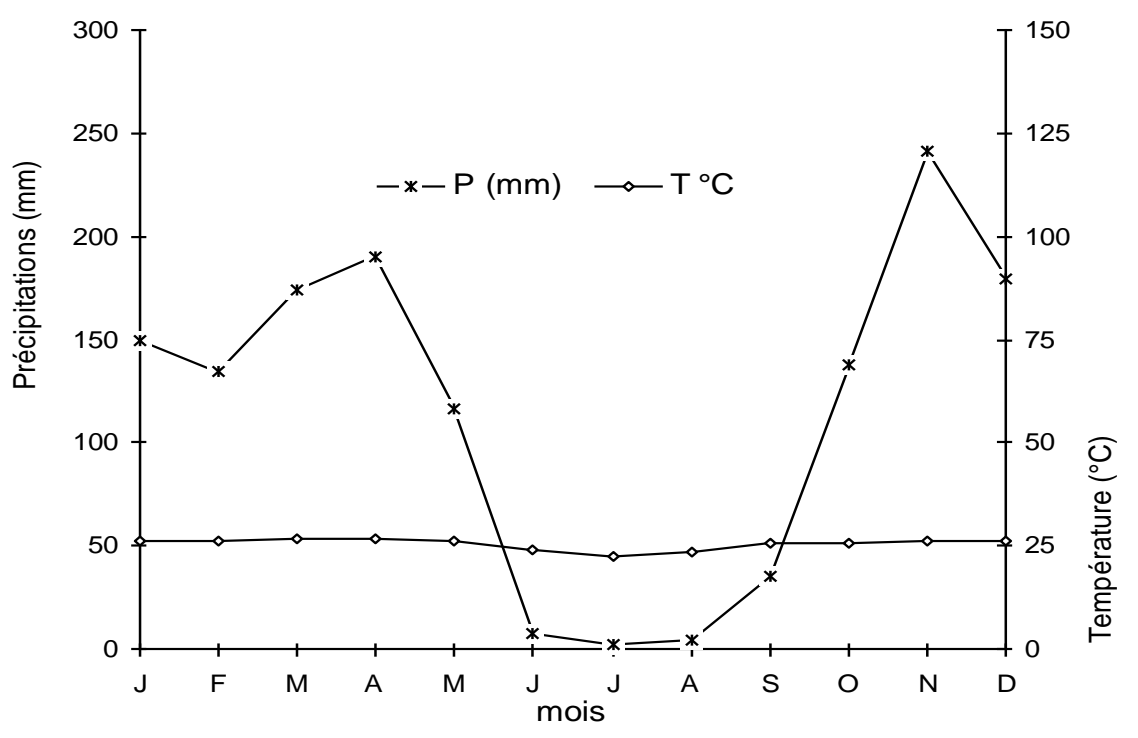


Fig.3 Views of some specimens of barked trees in Brazzaville urban area

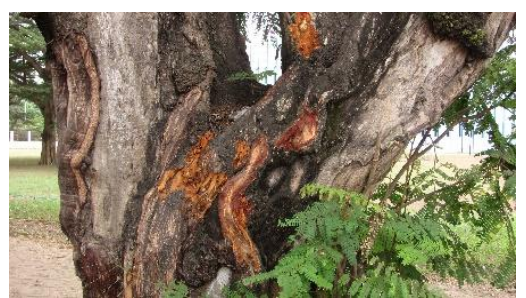

Peltophorum pterocarpum

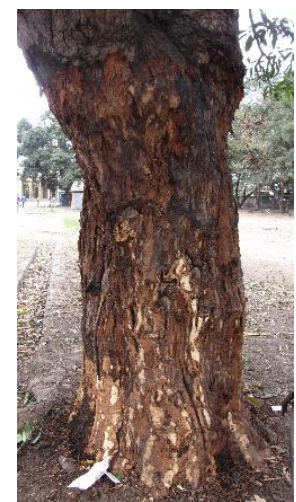

Mangifera indica(ringed)

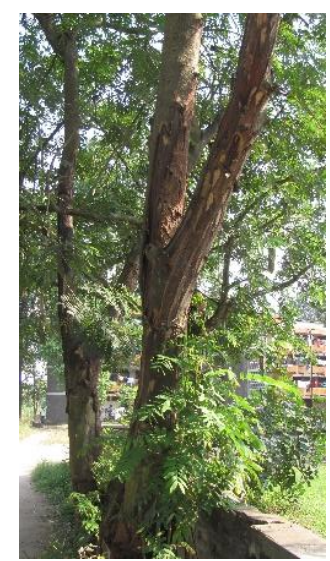

Senna siamea

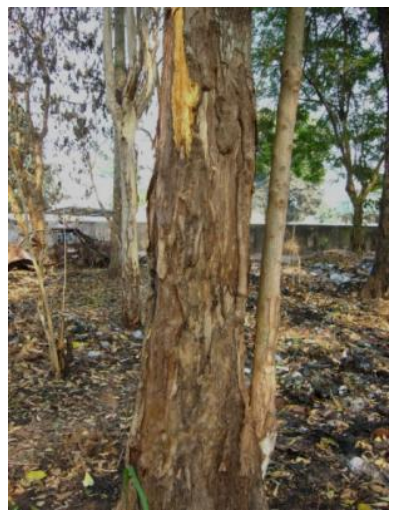

Terminalia superba

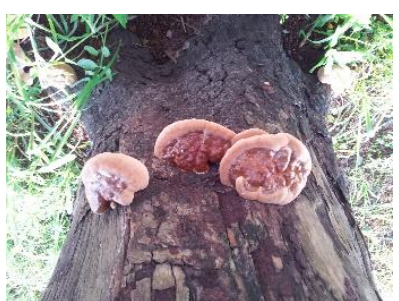

Fungus on Senna siamea

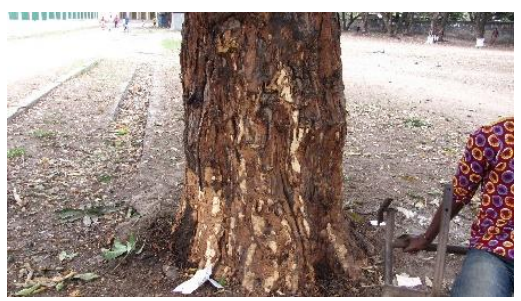

Mangifera indica (ringed)

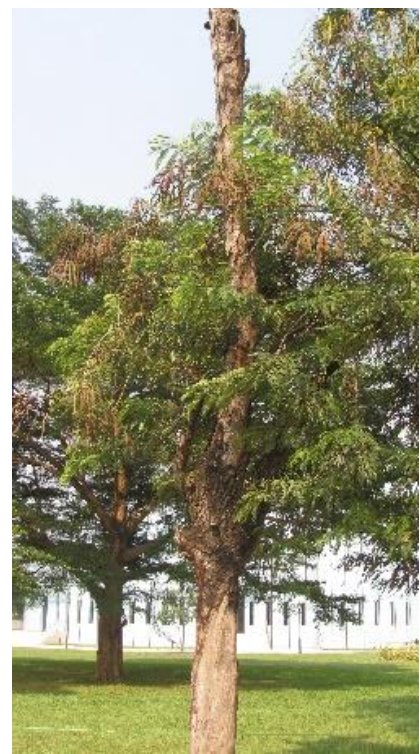

Senna siamea (dead on foot)

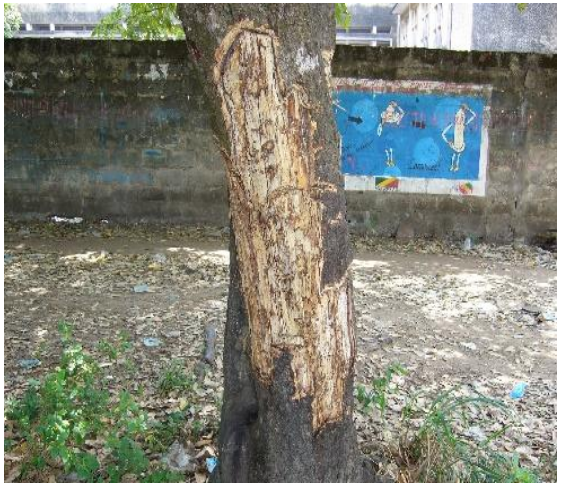

Millettia laurentii

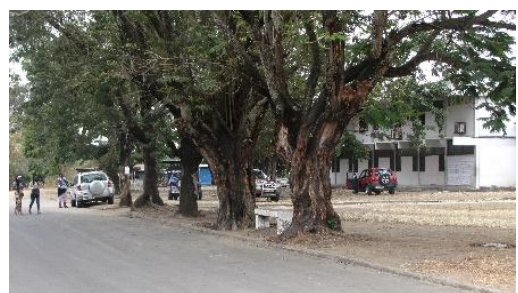

Peltophorum pterocarpum

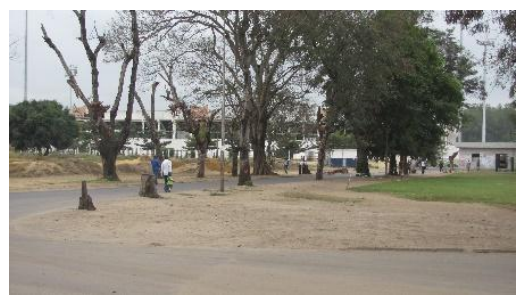

Senna siamea (dead on foot)

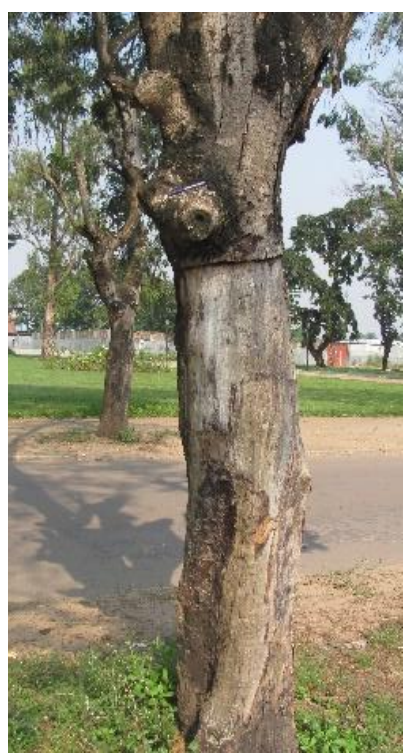

Senna siamea (ringed)

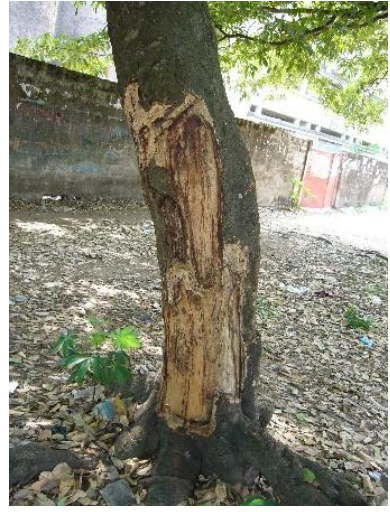

Millettia laurentii 
Fig.4 Operating spectrum of plant diversity by traditional healer

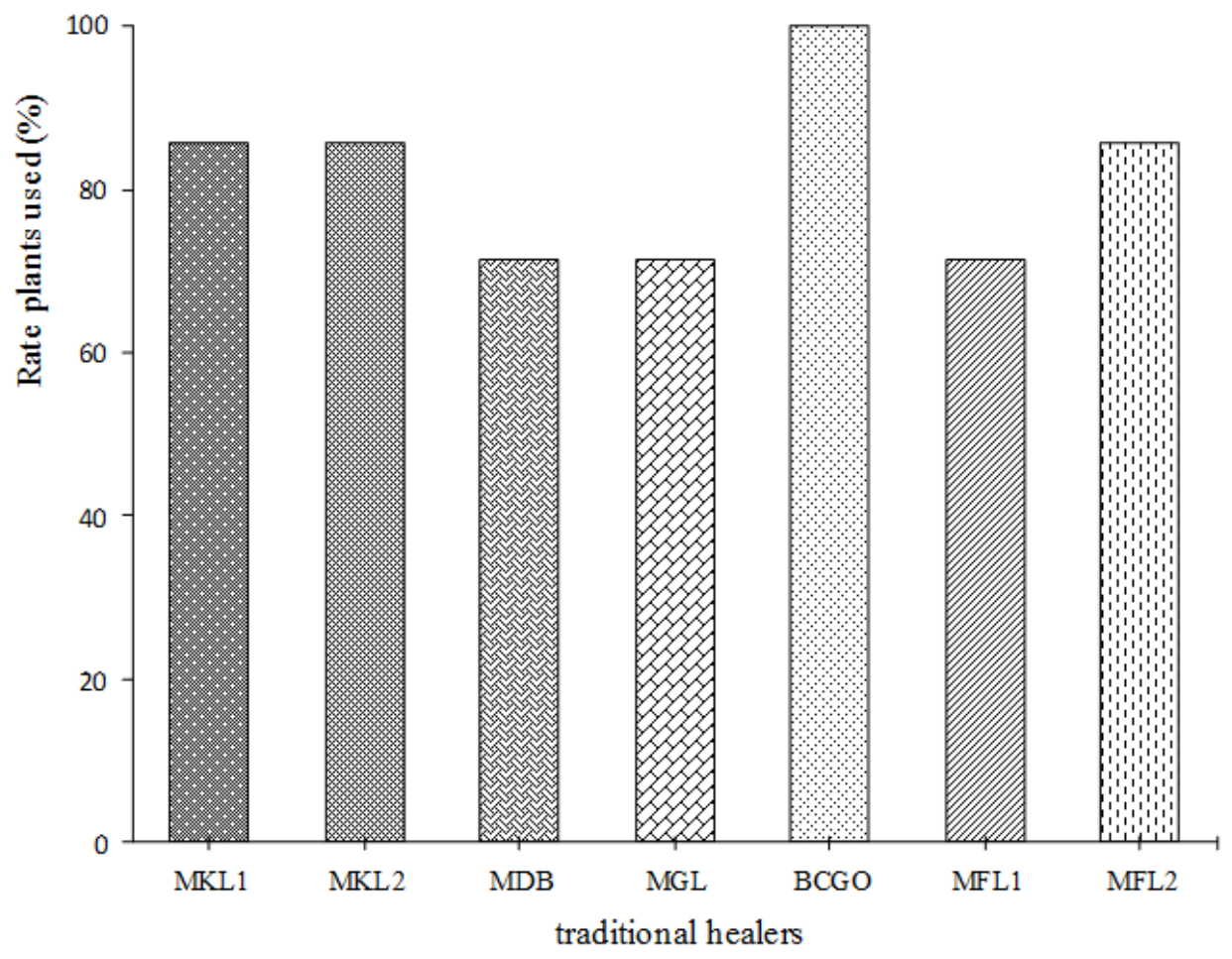

Fig.5 Convergence of herbal uses of taxa

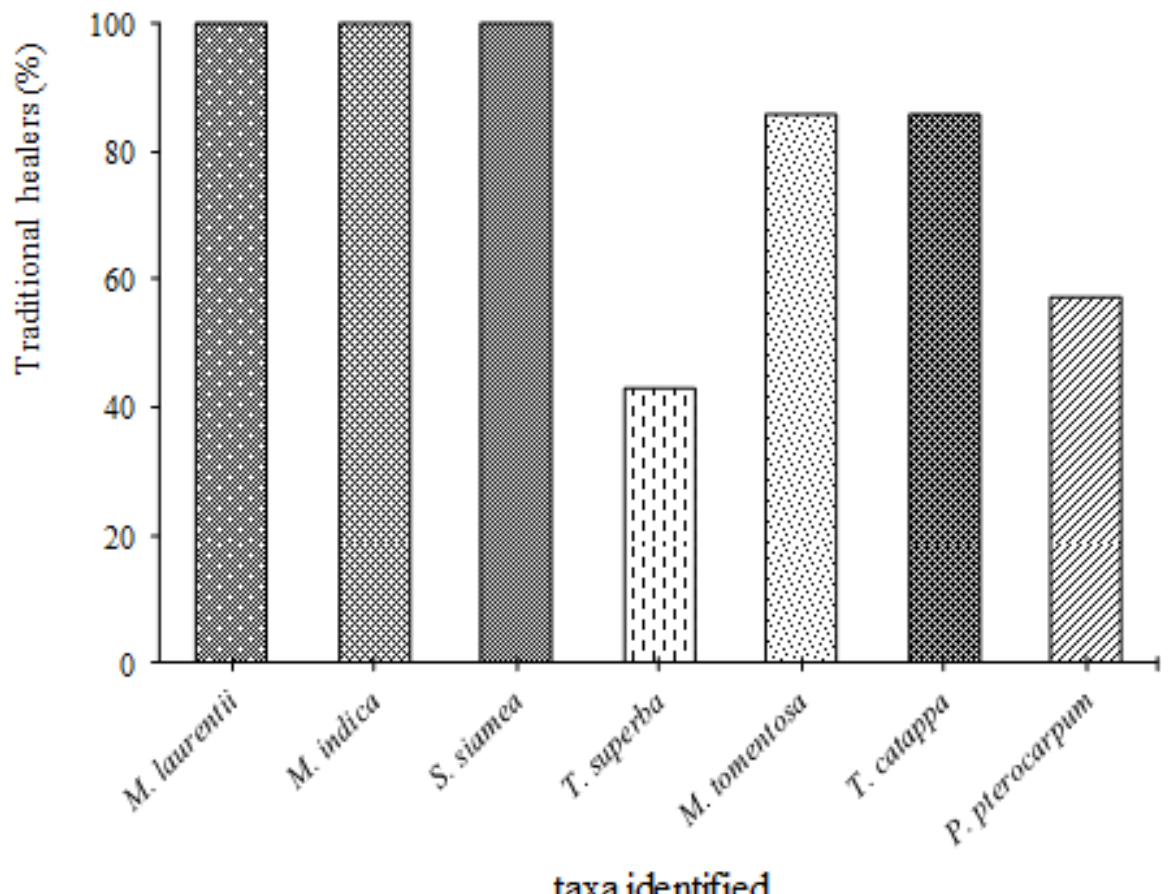


Fig.6 Report healers and diseases and / or symptoms treated

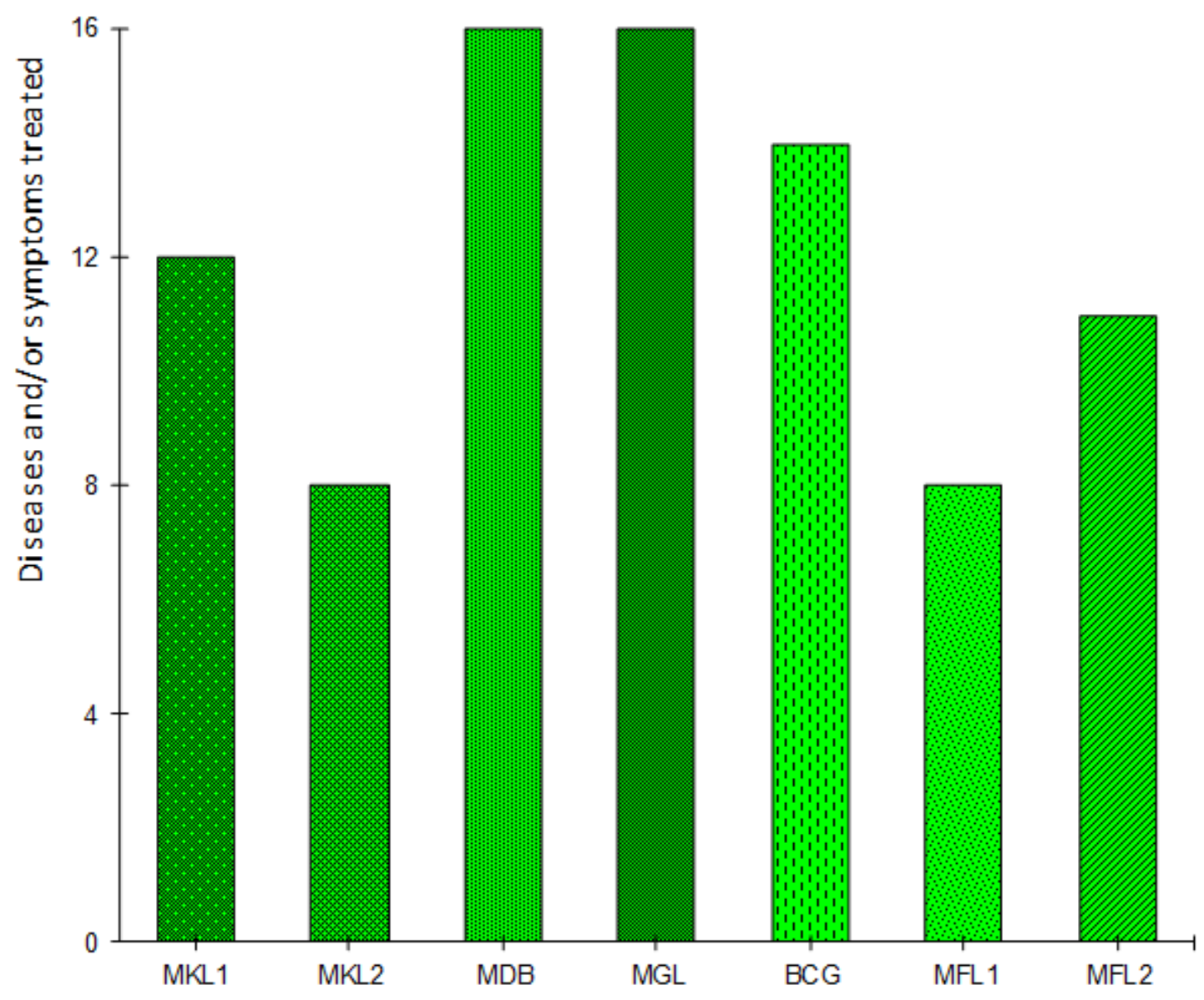

Fig.7 Disease prevalence and symptoms of organ sphere

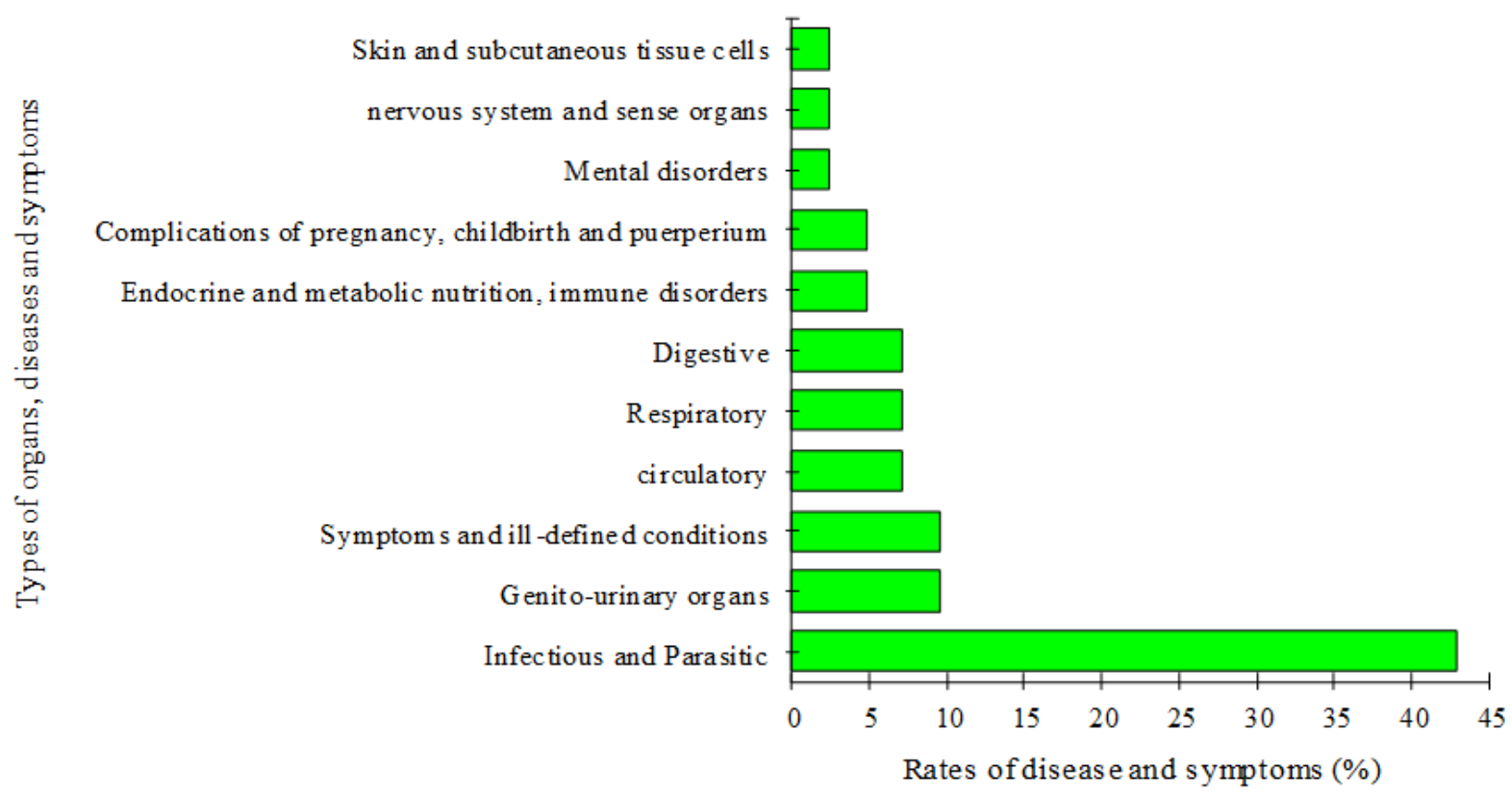


Int.J.Curr.Res.Aca.Rev.2017; 5(7): 38-51

Table.1 Synthetic data of the floristic inventory and ethnobotany

\begin{tabular}{|c|c|c|c|c|c|}
\hline Taxa & Status & $\mathrm{TP}$ & PU & Diseases and Symptoms & $\begin{array}{c}\text { Other citations in the geographical } \\
\text { area }\end{array}$ \\
\hline $\begin{array}{l}\text { Anacardiaceae } \\
\text { Mangifera indica L. }\end{array}$ & $\begin{array}{l}\text { Subspontaneous } \\
\text { and cultivated } \\
\quad \text { (exotic) }\end{array}$ & Pant & $\begin{array}{l}\text { Bark of } \\
\text { stem and } \\
\text { root }\end{array}$ & $\begin{array}{l}\text { Diarrhoea, genital irritation, } \\
\text { stomachache and stomach, } \\
\text { hyperglycemia, haemorrhoids, } \\
\text { stomatitis, inflammation, angina, } \\
\text { prickly heat, pain. }\end{array}$ & $\begin{array}{l}\text { Raponda-Walker and Sillans, 1961; } \\
\text { Bouquet, 1969; Adjanohounet al., } \\
\text { 1988; Lavergne and Véra, 1989; } \\
\text { Hecketsweiler and MokokoIkonga, } \\
\text { 1991; Kimpouni and Koubouana, } \\
\text { 1997; Lakouéténéet al., 2009; Betti } \\
\text { et al., 2013. }\end{array}$ \\
\hline $\begin{array}{l}\text { Bignoniaceae } \\
\text { Markhamia tomentosa } \\
\text { (Benth.) K. Schum. and } \\
\text { Thonn. }\end{array}$ & $\begin{array}{l}\text { spontaneous and } \\
\text { cultivated }\end{array}$ & $\mathrm{GC}$ & $\begin{array}{l}\text { Bark of } \\
\text { stem and } \\
\text { root }\end{array}$ & $\begin{array}{l}\text { Syphilis, hernia, stomach aches, } \\
\text { sexual asthenia. }\end{array}$ & $\begin{array}{l}\text { Raponda-Walker and Sillans, 1961; } \\
\text { Bouquet, } 1969 .\end{array}$ \\
\hline $\begin{array}{l}\text { Combretaceae } \\
\text { Terminalia catappa L. }\end{array}$ & cultivated (exotic) & Pant & $\begin{array}{l}\text { Bark of } \\
\text { stem }\end{array}$ & $\begin{array}{l}\text { Dysentery, intestinal worms, } \\
\text { diabetes, hypertension. }\end{array}$ & $\begin{array}{l}\text { Raponda-Walker and Sillans, 1961; } \\
\text { Lavergne and Véra, 1989; Tramil 4, } \\
\text { 1989; Diafouka and Lejoly, } 1993 .\end{array}$ \\
\hline $\begin{array}{l}\text { Terminalia superba Engl. and } \\
\text { Diels }\end{array}$ & $\begin{array}{l}\text { cultivated } \\
\text { (exotic) }\end{array}$ & $\mathrm{GC}$ & $\begin{array}{l}\text { Bark of } \\
\text { stem }\end{array}$ & $\begin{array}{l}\text { Infant diarrhea, ovarian disorder, } \\
\text { infertility, threatened abortion and } \\
\text { miscarriage. }\end{array}$ & $\begin{array}{l}\text { Bouquet, 1969; Hecketsweiler and } \\
\text { Mokokolkonga, 1991; Kimpouni and } \\
\text { Koubouana, } 1997 .\end{array}$ \\
\hline $\begin{array}{l}\text { Fabaceae } \\
\text { Millet tialaurentii De Wild. }\end{array}$ & $\begin{array}{l}\text { spontaneous and } \\
\text { cultivated } \\
(\text { exotic })\end{array}$ & CG. & $\begin{array}{l}\text { Bark of } \\
\text { stem }\end{array}$ & $\begin{array}{l}\text { Cough, asthma, infertility, aches, } \\
\text { hernia, dysmenorrhea, leprosy, } \\
\text { ringworm, fungal infections, } \\
\text { dermatitis, chickenpox, epilepsy. }\end{array}$ & $\begin{array}{l}\text { Bouquet 1969; Adjanohounet al., } \\
\text { 1988; Profiziet al., } 1993 .\end{array}$ \\
\hline $\begin{array}{l}\text { Senna siamea (Lam.) Irwin } \\
\text { and Barneby }\end{array}$ & $\begin{array}{l}\text { subspontaneous } \\
\text { and cultivated } \\
\text { (exotic) }\end{array}$ & Pant & $\begin{array}{l}\text { Bark of } \\
\text { stem and } \\
\text { root }\end{array}$ & $\begin{array}{l}\text { Hemorrhoids, dysmenorrhea, } \\
\text { hernia, malaria, stomach pain, } \\
\text { infertility, hypertension and } \\
\text { hypotension, cough. }\end{array}$ & $\begin{array}{l}\text { Diafouka and Lejoly, 1993; Qiu-Fen } \\
\text { et al., 2002; Lakouéténéet al., 2009; } \\
\text { NsondeNtandouet al., 2010, 2015, } \\
\text { 2016; MotalibMomin, 2012; } \\
\text { Mamadou et al., 2014. }\end{array}$ \\
\hline $\begin{array}{l}\text { Peltophorum pterocarpum } \\
\text { (DC.) Bak. ex. K. Heyne }\end{array}$ & $\begin{array}{l}\text { cultivated } \\
\text { (exotic) }\end{array}$ & Pant & $\begin{array}{l}\text { Bark of } \\
\text { stem and } \\
\text { root }\end{array}$ & $\begin{array}{l}\text { High blood pressure, diarrhea, } \\
\text { stomach pain, stomach upset. }\end{array}$ & $\begin{array}{l}\text { Mabberley, 1988; Jashet al., 2013; } \\
\text { Voravuthikunchaiet al., } 2004\end{array}$ \\
\hline
\end{tabular}

Legend: phytogeography types (TP), part used (PU), pantropical (Pant), Guineo-Congolese (GC), Centro Guinea (CG). 
Table.2 Synopsis of the extent of shelling of therapeutic use trees

\begin{tabular}{|c|c|c|c|c|}
\hline \multirow[t]{2}{*}{ Species } & \multicolumn{2}{|c|}{$\begin{array}{l}\text { Number of } \\
\text { individuals }\end{array}$} & \multirow{2}{*}{$\begin{array}{c}\text { Mean } \\
\text { diameter } \pm \text { ES } \\
\text { trees }(\mathbf{m})\end{array}$} & \multirow{2}{*}{$\begin{array}{l}\text { Average surface } \\
\pm \text { ES peeled per } \\
\text { tree }\left(\mathbf{m}^{2}\right)\end{array}$} \\
\hline & Total & Barked & & \\
\hline Mangifera indica & 3037 & $276(9,09 \%)$ & $0,42 \pm 0,01$ & $1,82 \pm 0,08$ \\
\hline Markhamia tomentosa & 32 & $6(18,75 \%)$ & $0,20 \pm 0,00$ & $1,55 \pm 0,32$ \\
\hline Terminalia catappa & 265 & $81(30,57 \%)$ & $0,26 \pm 0,02$ & $1,28 \pm 0,12$ \\
\hline Terminalia superba & 55 & $20(36,36 \%)$ & $0,58 \pm 0,08$ & $1,85 \pm 0,42$ \\
\hline Millettialaurentii & 551 & $224(40,65 \%)$ & $0,40 \pm 0,01$ & $1,87 \pm 0,11$ \\
\hline Peltophorum pterocarpum & 258 & $143(55,43 \%)$ & $0,55 \pm 0,03$ & $3,15 \pm 0,14$ \\
\hline Senna siamea & 336 & $187(55,65 \%)$ & $0,31 \pm 0,01$ & $1,42 \pm 0,13$ \\
\hline
\end{tabular}

Despite these many applications, non-ecological mechanisms of barks collection cannot guarantee the longevity of the wood potential. In spite of senescence which affects this population, because of the nonrenewal of individuals, the removal of bark opens injuries that affect individuals can not heal. This action which reaches the sapwood, takes off the seat cambial and deprives at any of potential to regenerate tissue and / or organ removed. While affecting physiological functions, it opens gateways to pathogens of all types and severely alters the morphology of individuals (Heller et al., 1998, 2000).

\section{Induced effects of the removal of organs}

The sampling mechanism and type of involved organs weaken individuals or plant populations constituting the therapeutic source (Guedje, 1996). Indeed, the role of roots and barks in (i) completion of the metabolic functions is more established, like that of (ii) support and protect internal organs (Heller et al., 1998, 2000). Despite the death of individuals on foot, because of the uncontrolled stripping barks of trees they are victims of, we see witches broom phenomena, secondary defects in trunks, and sometimes discharges at the base. Without following generative parameters, literature data show that they are generally affected by the removal of vegetative organs.

Except Markhamia tomentosa and Mangifera indica that are found accidentally in the plots of some traditional healers and vacant lots, all taxa are always under the control of urban administration. Apart from senescence that undermines different taxa on the one hand, and on the other hand, the sampling mechanism of the organs that has not low-impact, the peeling trees cannot support the strong anthropic pressure they are submitted to. It is also interesting to note that the city manager does not replace the dead subjects and does not assure the renewal trees of avenue. The combined effects of these two parameters are indicative of the inevitable extinction of this natural bioressource in the short term. This situation is so plausible that no traditional therapist has thought to cultivate only but one foot of such taxa, to overcome the disappearance of the phytoressource. Although the majority of taxa are anemochores, the inventory of vacant land reveals a deficit of natural regeneration of such taxa.

An analysis of the type of bark revealed that taxa fibrous texture of Peltophorum pterocarpum, Markhamia tomentosa, Terminalia catappa, Millet tialaurentii are more tolerant to the phenomenon of stripping of bark trees. During the organ harvesting operation, small cambium strips remain present at the wound.

The bark cannot detach in uniform plate in these taxa, this property promotes optimal wound healing. The threat that affects these taxa, including Peltophorum pterocarpum and Mangifera indica, is the sampling frequency because of their involvement in the treatment of emerging diseases (hypertension, diabetes), abdominal pain and stomach aches.

These species are less prone to mortality of individuals. However, the situation is different with Senna siamea. This species has a thin crust, grainy, brittle, breaking away, taking the seat cambial. Thus, tissue renewal on the stripped part is almost impossible. The implication of this taxon in treatments for scourges like malaria, hypertension, stomach aches and abdominal pain corollaries a prevalence of organ removal, leading more often to anneal the subjects who are victims. The metabolism of individuals being disrupted, we noted a significant number of dead subjects on foot, for this species. 


\section{Ecological role of trees}

Urban forestry is now an investigative field of choice which has gained great importance in the management of plant biodiversity. No urban city whatever its rank does not pay special attention to this sector (FAO, 2001; Cost, 2005; Alvey, 2006; Konijnendijk et al., 2006; Fuwape and Onyekwelu, 2011). In the Republic of Congo and particularly in Brazzaville which is named "Brazza green", with reference to its forest cover, cannot merit this designation, if Brazzaville city loses its forest cover. The services rendered by tree crops can be divided into two areas: (i) direct and (ii) indirect (Convery, 1990). The direct elements are very often associated with social anthropology (nutrition, medicine, crafts, wood energy, aesthetic and shade). Their impact level is limited to the population needs (Cunningham, 1997; Bergonzini, 2004), minor entity compared to globally benefits of the trees. In the case of taxa of this study, they are indirect benefits that are paramount, especially facing the global challenge of climate change (Bergonziniand Lanly, 2000). Some of the benefits include but not limited to the retention of dust, the fight against erosion, climate regulation, carbon sequestration, etc. Referring to the benefits that draw from urban forestry, it is more than absolute to have a sustainability plan for all these taxa, whose interest is well established. Let us emphasize that they constitute the bulk of avenues of trees, next to Terminalia mantaly.

\section{Ethnobotanical value}

Phytogeographic data covered $57 \%$ of non-native taxa in the Guinean-Congo area, this element authenticate ownership of exotic customs. Practicing these companies on empirical knowledge transmission is based on oral clan rituals or lineage. As such, any new knowledge can only come from a contact or a merging of knowledge among people. The interest that reveals new knowledge acquisition is the sustained use of plant biodiversity to reach. The fact that pharmacognosics properties are recognized in these taxa, in their area of origin, supports this hypothesis.

According to WHO (1975), therapeutic indications are classified into 17 major groups of diseases and symptoms, for which the recipe is proposed. This study based on a relatively small number of taxa (7) covers $6.71 \%$ of the aforementioned groups, for thirty diseases and symptoms. As part of traditional medicine, the analysis of therapeutic indications retains three plagues of major interest, according to the priorities of the African office of the World Health Organization (WHO). It is about diabetes, malaria and high blood pressure which are highlighted as emerging diseases.

Given the variety of illnesses that people are face to, the resulting pharmacognoic of this source comes in herbal medicine: antibiotic, analgesic, anthelmintic, antidiarrhea, anti-abortive, expectorant, aphrodisiac, antispasmodic, antifungal, disinfectant and astringent, and as can be inferred, the physiological effects are numerous and affect more than one sphere of organs and / or diseases and symptoms. On (i) the central nervous system were noted depressant effects (analgesic, antiodontalgic, neuralgic, autonomous (antispasmodic), antipyretic, sedative), exciting (exciting general); the (ii) vascular (blood pressure lowering, antihypertensive); the (iii) respiratory system (antitussive, expectorant); on (iv) pathogenic or parasitic organisms (anthelmintic, anthelmintic, anti-malarial, vermicide, dysentery, antibiotic, antifungal); (v) topical skin (skin antiseptic); (vi) effects on the intestine (antidiarrheal); (vii) the effect in relation to the glandular systems; (viii) effects on the reproductive system (aphrodisiac); (ix) impact on inflammation (anti-inflammatory).

\section{Analysis of therapeutic indications}

Despite some use of discrepancies identified in the phytogeographical areas, these plants are used for the same purposes in traditional medicine (Raponda-Walker and Sillans, 1961; Sofowora, 1986; Adjanohoun et al., 1988; Lavergne and Vera, 1989; Hecketsweiler et al., 1991; Doumenge, 1992; Kimpouni and Koubouana, 1997). At the current stage of knowledge, these achievements can be interpreted as a proven certification of their medicinal properties. These variations of uses reflect the knowledge base of each ethnic entity and / or clan, and thus the sign of its intrinsic value (Kimpouni et al., 2013c). The fact that a plant is referred to more than one disease and / or symptoms, is not bias, since the phytochemical analyses show more than one active per species, or even an individual (Sofowora, 1986).

Urban forestry is a vital element for maintaining a healthy environment. The rapid urbanization of the city coupled with rapid population growth and urban migration among which a higher fringe of the poor people, are the plagues that affect urban forests. In Brazzaville, on one hand, the study based on observation of stripping bark trees, highlights the virtues of urban 
forestry, and on the other hand, the negative impact of human behavior on the trees of that urban forestry. Finally, this study revealed that, despite the obvious benefits that the people and humanity draw from it, the urban forest is endangered if sustainable management measures are not adopted. The floriculture of Brazzaville is an important herbal source for populations. The level of poverty and the prohibitive costs of medical care "qualities" have as corollaries, the resurrection of slumbering sociocultural heritage in each individual. Given the role and function of that flora in the welfare of people and the city, and anthropogenic effects which it is subjected, a management strategy requires us to avoid the disappearance of this resource. To overcome this inevitable extinction of Brazzaville floriculture, managers of the city should raise awareness and possibly communicate with the world of education to reach a maximum number of people, especially the young and educated population.

\section{References}

Adjanohoun, E., A.Ahyi,L.AkéAssi, J.Baniakina,G.Chibon, P. Cusset, V. Doulou, A. Nzanza, J. Eyme, E. Goudote, A. Keita, C. Mbemba, J. Mollet, J.-M. Moutsamboté, J.B. Mpati and Sita, P. 1988. Contribution aux études ethnobotaniques et floristiques en République Populaire du Congo, ACCT, Paris. Pp. 1-605.

Alvey, A.A. 2006. Promoting and preserving biodiversity in the urban forest. Urban Forestry and Urban Greening. 5: 195-201. doi:10.1016/j.ufug.2006.09. 003

APG III. 2009. An update of the Angiosperm phylogeny group classification for the orders and families of flowering plants. APG III. Botanical Journal of the Linnean Society. 161:105-121.

Aubréville, A. 1949. Climats, forêts et désertification de l'Afrique tropicale. Société d'éditions géographiques, maritimes et coloniales, Paris. Pp. 1351.

Bergonzini, J.-C. 2004. Changements climatiques, désertification, diversité biologique et forêts. SilvaRIAT, Paris. Pp. 1-146.

Bergonzini, J.-C. and Lanly, J.-P. 2000. Les forêts tropicales. Karthala, CIRAD, Paris. Pp. 1-166.

Betti, J.L., D. MidokoIponga, D.O.Yongo, D. Obiang Mbomio, C. Mikolo Yobo and Ngoy, A. 2013. Ethnobotanical study of medicinal plants of the Ipassa-Makokou Biosphere Reserve, Gabon. Plants used for treating malaria. Journal of Medicinal Plants Research. 7 (31): 2300-2318. doi: 10.5897/JMPR11.1754.
Bouquet, A. 1969. Féticheurs et médecines traditionnelles du Congo (Brazzaville). Mémoire ORSTOM 36, Paris. Pp. 1-282.

Convery, F.J. 1990. Intégration d'un processus de plan national d'action pour l'environnement dans un cadre macro-économique. Plans nationaux d'action pour l'environnement en Afrique. Compte rendu d'un atelier organisé par le gouvernement Irlandais, l'institut pour l'environnement, UniversityCollege de Dublin et la Banque Mondiale (EDIAR et AFTEN). Dublin, Irlande (du 13-14 décembre 1990), Dublin. Pp. 33-47.

Cosson, J. 1955. Notice explicative sur les feuilles, PointeNoire et Brazzaville. Carte de reconnaissance à l'échelle 1/ 50000, ORSTOM, Paris. Pp. 1-56.

COST Action E12. 2005. Urban forests and trees, Proceedings No 2. InKonijnendijk, C.C., J. Schipperijn and Nilsson, K. (Eds.), Forests and forestry products, Bruxelles. Pp. 1-300.

Cunningham, A.B. 1997. Revue de la documentation ethnobotanique relative à l'Afrique orientale et australe. Bulletin Réseau Africain d'Ethnobotanique. 1: $23-87$.

Denis, B., 1970. Les sols de la région de Brazzaville. ORSTOM, Paris. Pp. 1-93.

Diafouka, A. andLejoly,J. 1993. Plantes hypotensives utilisées en médecinetraditionnelle à Brazzaville (Congo). In Médicaments et al.,iments,l'Approche Ethnopharmacologique. Actes du $2^{\mathrm{e}}$ Colloque Européen d'Ethnopharmacologie et de la $11^{\mathrm{e}}$ Conférence internationale d'Ethnomédecine, Heidelberg (2, 4-27 mars 1993).Pp. 277-279.

Doumenge, C. 1992.La réserve de Conkouati, Congo: le secteur Sud-ouest. UICN, Gland. Pp. 1-213.

Duvigneaud, P. 1980.La synthèse écologique. Doin, Paris. Pp. 1-380.

FAO, 2001.La foresterie urbaine et périurbaine: Études de cas sur les pays en développement. Rome. Pp. 1-207.

Fleury, M. 1994. Impact de la traite des esclaves sur la phytogéographie: exemple chez les Aluku (Boni) de Guyane française. Journal d'Agriculture Traditionnelle et de Botanique appliquée, nouvelle série. 36 (1): 113-134.

Fuwape, J.A. and Onyekwelu, J.C. 2011. Urban Forest Development in West Africa: Benefits and Challenges. Journal of Biodiversity andEcological Sciences. 1(1): 77-94.

Gakosso, G. 2009. Diversité floristique et potentialité régénérative des îlots forestiers naturels de la Patte d'Oie. Mém. Certificat d'Aptitude au Professorat de l'Enseignement Secondaire (CAPES) Sc. Nat., Université Marien Ngouabi, Brazzaville. 
Guedje, N.M. 1996. Évaluation écologique de quelques Produits Non Ligneux de la région de Bipindi-Akom II: abondance, distribution et impact des récoltes sur les peuplements. Yaoundé, Programme Tropenbos Cameroun. Yaounde. Pp. 1-40.

Hecketsweiler, P. andMokokoIkonga,J. 1991.La réserve de Conkouati: Congo: le secteur sud-est.UICN, Gland. Pp. 1-334.

Hecketsweiler, P., C. Doumenge, andMokokoIkonga, J. 1991. Le Parc National d'Odzala, Congo. Gland, UICN. Pp. 1-321.

Heller, R., R. Esnault and Lance, C. 1998. Physiologie végétale, nutrition. Dunod, Paris. Pp.1-244

Heller, R., R. Esnault, and Lance, C., 2000. Physiologie végétale, développement. Dunod, Paris. Pp. 1-215 http://dx.doi.org/10.1007/s00704-007-0298-0

International Journal of Climatology, 32, 854-873. doi: 10.1002/joc. 2311.

Jash, S.K., R.K. Singh, S. Maji, A. Sarkar and Gorai, D. 2013. Peltophorum pterocarpum: Chemical and Pharmacological aspects. Int. J. Pharm. Sci. Res. 5(1): 26-36. doi: 10.13040/IJPSR.0975-8232.5(1).

Kiangana-Ngoyi, L. and Kalath, S.R. 2000. Flores arboricole et parasite de l'écosystème urbain Brazzavillois: plantes vasculaires (BrazzavilleCongo).Mém. Certificat d'Aptitude au Professorat de l'Enseignement Secondaire (CAPES) Sc. Nat., Université Marien Ngouabi, Brazzaville.

Kimpouni, V. and Koubouana, F. 1997. Etude ethnobotanique sur les plantes médicinales et al.,imentaires dans et autour de la réserve de Conkouati, Rapport final. PROGECAP/GEF-Congo, UICN, Brazzaville. Pp. 1- 65.

Kimpouni, V., E. Apani, P. Mbou and Motom, M. 2014.Etude floristique des îlots forestiers naturels de la Patte d'Oie de Brazzaville, Congo.ActaBotanicaGallica. 161(1): 63-79.doi: 10.1080/12538078.2013.870048online:http://dx.doi. org/10.1080/12538078.2013.870048

Kimpouni, V., M. Motom and Apani, E. 2013c. Valeurs socioculturelles et gestion de la diversité génétique d'Elaeis guineensis(Arecaceae) en République du Congo.ScriptaBotanicaBelgica. 50: 391-398.

Kimpouni, V., P. Mbou, G. Gakosso, and Motom, M. 2013b.Biodiversité floristique du sous-bois et régénération naturelle de la forêt de la Patte d'Oie de Brazzaville, Congo. International Journal of Biological and Chemical Science.7 (3):1255-1270. doi: 10.4314/ijbcs.v7i3.31

Kimpouni, V., P. Mbou, E. Apani and Motom, M. $2013 \mathrm{a}$. Floristic diversity and structural parameters of the Brazzaville Patted'Oie forest, Congo. Open Journal of Ecology. 3(8):518-531.
Konijnendijk, C.C., R.M. Ricard, A. Kenney and Randrup, T.B. 2006. Defining urban forestry - A comparative perspective of North America and Europe. Urban Forestry et Urban Greening.4 (3-4): 93-103.

Koussibila-Dibansa, G.M., Makaya, D., 1997. Contribution à l'étude de la flore des jardins de cases de Brazzaville: Cas de Moukoundzi-Ngouaka.Mém. Certificat d'Aptitude au Professorat de l'Enseignement Secondaire (CAPES) Sc. Nat., Université Marien Ngouabi, Brazzaville.

Lakouéténé, D.P.B., G. Ndolngar, B. Berké, J.-M. Moyen, E. KoshKomba, I. Zinga, S. Silla, J. MillogoRasolodimby, P. Vincendeau, J.-L. Syssa-Magalé, O.G. Nacoulma-Ouedraogo, R. Laganier, A. Badoc and Chèze, C. 2009. Enquête ethnobotanique des plantes utilisées dans le traitement du paludisme à Bangui. Bull. Soc. Pharm. Bordeaux.148: 123-138.

Lavergne, R. and Véra, R. 1989.Étude ethnobotanique des plantes utilisées dans la pharmacopée traditionnelle à la Réunion. Médecine traditionnelle et pharmacopée, ACCT, Paris. Pp. 1-236.

LEBRUN J.-P. and A. L. STORK (19912015). Enumération des plantes à fleurs d'Afrique tropicale et Tropical African Flowering Plants: Ecology and Distribution, vol. 110. Conservatoire et Jardin botaniques de la Ville de Genève,

Mabberley, D.J., 1993. The plant-book: A portable dictionary of the higher plants.Cambridge University Press, London. Pp. 1-707.

Mamadou, K., C. Koffi, M.K.N'goran, A. Akoubet, A.R.Y.N'guessanand Die-Kakou, H.M.2014. Ethnobotany, phytochemistry, pharmacology and toxicology profiles of Cassia siamea Lam. The Journal of Phytopharmacology. 3(1): 57-76.

Martin G. J., 2004 - Ethnobotany: amethodsmanual. People and plants conservation series, Earthscan, London. Pp. 1-268.

Mbou, P. 2009. Structure et typologie des îlots forestiers naturels de la Patte d'Oie (Brazzaville). Mém. Certificat d'Aptitude au Professorat de l'Enseignement Secondaire (CAPES) Sc. Nat., Université Marien Ngouabi, Brazzaville.

Mbouba, S.D. 2007.Importance et aspects biogéographiques de la flore ligneuse allochtone à Brazzaville. Mém. Certificat d'Aptitude au Professorat de l'Enseignement Secondaire (CAPES) Sc. Nat., Université Marien Ngouabi, Brazzaville.

Motalib Momin, M.A., Sm. F. Bellah, K. Afrina Afrose, K. Fatima Urmi, Sohel Rana and Hamid, Md. 2012. Phytochemical screening and cytotoxicity potential of ethanolic extracts of Senna siamea Leaves. J. Pharm. Sci. et Res. 4(8): 1877-1879. 
Mounié, A. 1999. Connaissances et Identification Pratique des Arbres du Campus de l'Ecole Normale Supérieure et du Rectorat (Brazzaville-Congo). Mém. Certificat d'Aptitude au Professorat de l'Enseignement Secondaire (CAPES) Sc. Nat., Université Marien Ngouabi, Brazzaville.

Ndembe Vouezolo Pemba, F. 2008.Données biologiques et écologiques des Ficus étrangleurs de la flore de Brazzaville. Mém. Certificat d'Aptitude au Professorat de l'Enseignement Secondaire (CAPES) Sc. Nat., Université Marien Ngouabi, Brazzaville.

Niamba, L. 2007.Données biologiques et écologiques des Ptéridophytes sauvages de l'écosystème urbain brazzavillois. Mém. Certificat d'Aptitude au Professorat de l'Enseignement Secondaire (CAPES) Sc. Nat., Université Marien Ngouabi, Brazzaville.

Nkondi, A. and Mabiala-Tsimba, B.L. 1999. Identification, Classification et Dissémination des Fruits des arbres du campus de l'école normale supérieure et du rectorat (Brazzaville-Congo). Mém. Certificat d'Aptitude au Professorat de l'Enseignement Secondaire (CAPES) Sc. Nat., Université Marien Ngouabi, Brazzaville.

Nkounkou-Loufoukou, R.C. 2012.Savoirs endogènes ET conservation de la floriculture urbaine à Brazzaville. Mém. Certificat d'Aptitude au Professorat de l'Enseignement Secondaire (CAPES) Sc. Nat., Université Marien Ngouabi, Brazzaville.

NsondeNtandou G.F., D.J. Basoueka, J.T.Banzouzi, A.W.EtouOssibi, R.D.G.Elion Itou, M.C. Makambila, S. Ramos, F. Benoit-Vical, A.A. Abenaand Ouamba, J.M. 2015. Assessment of Cassia siameastem bark extracts toxicity and stability in time of aqueous extract analgesic activity. African Journal of Pharmacy and Pharmacology. 9(41): 988-994.

NsondeNtandou, G.F., D.J. Bassoueka, J.T. Banzouzi, R.D.G. Elion Itou, A.W. EtouOssibi, F. BenoitVical, J.M. Ouambaand Abena, A.A. 2016. Cassia siamea Lam. Extracts analgesic mechanism of action and pharmacodynamic interaction with paracetamol (acetaminophen).European Journal of Research in Medical Sciences. 4(1): 1-13.

NsondeNtandou, G.F., J.T. Banzouzi, B. Mbatchi, R.D.G. Elion-Itoua, A.W. EtouOssibi, S. Ramos, F. Benoit-
Vical, A.A. Abena and Ouamba, J.-M. 2010. Analgesic and anti-inflammatory effects of Cassia siameaLam. Stem bark extracts. Journal of Ethnopharmacology. 127:108-111.

Nzala, D. and Miankodila, P. 2002. Arbres et espaces verts à Brazzaville (Congo). Bois et Forêts des Tropiques. 272(2): 88-92.

Ozenda, P. 1982. Les végétaux dans la biosphère. Doin, Paris. Pp. 1-432.

Profizi, J.-P., J.-P. Makita-Madzou, J.C. Milandou, C.N. Karanda, M. Motom and Bitsindou, I. 1993. Ressources végétales non ligneuses des forêts du Congo. Plan d'Action Forestier Tropical du Congo (PAFT-Congo). Université Marien Ngouabi, Brazzaville. Pp. 1-67.

Qiu-Fen, H., Z. Bin, G.Xue-Mei, Y. Li-Ying, S. Li-Dan, S. Yanqiong, L. Gan-Peng, C. Chun-Tao and GuangYu, Y. 2012. Antiviral chromones from the stem of Cassia siamea. J. Nat. Prod.75 (11): 1909-1914.

Raponda-Walker, R.A. and Sillans, R. 1961. Les plantes utiles du Gabon. Lechevalier P., Paris. Pp. 1-614.

Samba G. and Nganga, D. 2011. Rainfall variability in Congo-Brazzaville: 1932-2007.

Samba, G., D. Nganga and Mpounza, M. 2008. Rainfall and temperature variations over Congo-Brazzaville between 1950 and 1998. Theor. Appl. Climatol.91:85-97.

Samba-Kimbata, M.-J. 1978. Le climat bas Congolais. Thèse de Doctorat, Université de Dijon, Dijon.

Sofowora, A. 1996. Plantes médicinales ET médecine traditionnelle d'Afrique. Karthala, Paris. Pp. 1-378.

Tramil 4. 1989. Vers une Pharmacopée Caraïbe, Recherche scientifique ET usage populaire des plantes médicinales dans la Caraïbe. Enda-Caraïbe, Honduras. Pp. 1-474.

Vennetier, P. 1977.Atlas de la République Populaire du Congo. Éditions Jeune Afrique, Paris. Pp. 1-64.

Voravuthikunchai, S., A. Lortheeranuwat, W. Jeeju, T. Sririrak, S. Phongpaichit, andSupawita, T. 2004. Effective medicinal plants against enterohaemorrhagic Escherichia coli O157:H7.J. Ethnopharmacol. 94(1): 49-54.

\section{How to cite this article:}

Victor Kimpouni, Marie-Yvette Lenga-Sacadura, Roche Collin Nkounkou-Loufoukou and Josérald Chaîph Mamboueni. 2017. Survey of the Anthropic Actions and the Urban Woody Flora Exploitation in Brazzaville (Congo). Int.J.Curr.Res.Aca.Rev. 5(7), 38-51. doi: https://doi.org/10.20546/ijcrar.2017.507.007 